add to the risk of incurring or increasing the severity of methylmercury poisoning.

This study was supported by the National Research Council of Canada.

\section{T. EDWARDS}

B. C. MCBRIDE

Department of Microbiology,

University of British Columbia,

Vancouver, British Columbia V6T 1W5, Canada

Received November 22, 1974.

1 Jensen, S., and Jernelöv, A., Nature, 223, 753-754 (1969).

Abdullah, M., Arnesjö, B., and Ihse, I., Svenska Läkartidingen, 71, 810-811 (1974).

3 Norseth, T., and Clarkson, T. W., Archs Environ. Health, 22, $568-577$ (1968).

4 Bryant, M. P., and Robinson, I. M., J. Dairy Sci., 44, 1446-1456 (1961).

Hungate, R. E., Bact. Rev., 14, 1-49 (1950).

Westöö, G., Acta Chem. scand., 22, 2277-2280 (1968).

7 Wood, J. M., Kennedy, F. S., and Rosen, C. G., Nature, 220, 173 (1968).

\section{Citrate in milk:}

\section{a harbinger of lactogenesis}

CONSIDERABLE amounts of citrate $(130-160 \mathrm{mg}$ per $100 \mathrm{ml})$ occur in the milk of cows and goats, and approximately half this amount in that of women. In spite of its central role in the metabolism of all cells, the significance of the presence of citrate in milk and its mode of secretion are not known'. We report that the final stage of lactogenesis is preceded by the onset of citrate secretion into colostrum.

Matured but previously quiescent epithelial cells suddenly start to secrete large quantities of protein, fat and carbohydrate at about the time of parturition. Although there are significant changes in plasma hormone concentrations in late pregnancy and at term, the nature of this lactogenic trigger remains unknown ${ }^{1,2}$. Cowie and Tindal ${ }^{2}$ have suggested that the presence

Fig. 1 Concentrations of citrate in the mammary secretion of $a$, a cow; $b$, a goat; and $c$, a woman about the time of parturition. Small samples were taken from the teat and analysed by the method of White and Davies ${ }^{10}$. In all species the young were suckled normally after parturition.

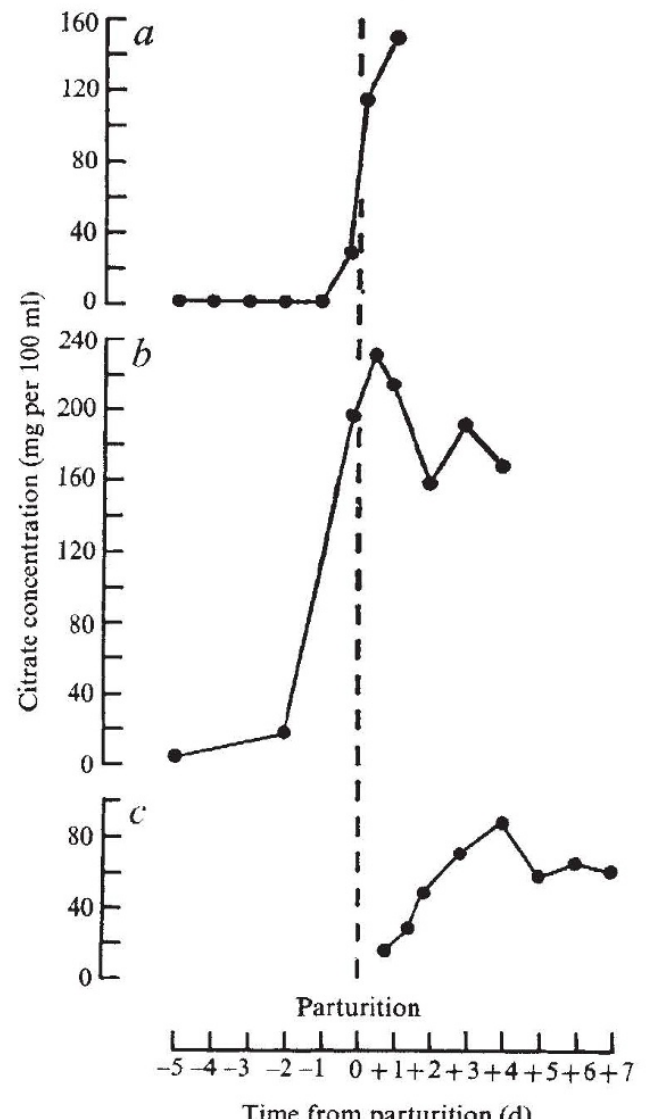

Time from parturition (d) in the secretory tissue of the relevant organelles, enzymes, substrates and some specific milk components, is not sufficient evidence for the onset of copious secretion. For example, udders of cows and goats may contain several litres of a fluid with almost normal milk lactose and ion concentrations 6-7 weeks before term, although copious secretion starts at about the time of parturition (ref. 3 and I. R. Fleet, J. A. Goode, M. H. Hamon, M. S. Laurie, J. L. L., and M: P., unpublished). The onset of secretory activity therefore occurs in two stages, and other investigations ${ }^{5,6}$ have in fact only covered the first stage ${ }^{4,5}$.

The rate of onset of copious secretion is indeed impressive; in cows the yield may be as high as $401 \mathrm{~d}^{-1}$ within a few days after parturition and $41 \mathrm{~d}^{-1}$ in goats. The mammary glands need about $70 \mathrm{~g}$ glucose per litre milk formed to support secretion $^{8}$, and although mammary blood flow increases markedly before parturition in goats and $\operatorname{cows}^{7,8}$ the uptake of glucose and oxygen does not begin until immediately after parturition and then reaches high levels within a few hours ${ }^{8}$.

In milk from seven goats and seven cows, citrate concentration increased by 3-150 times (median for goats 10 times, for cows 46 times) 1-2 d pre-partum and 2-3 d post-partum (Fig. 1). This rapid increase is illustrated by data from a cow in which the citrate concentration increased from 7 to $110 \mathrm{mg}$ per $100 \mathrm{ml}$ in the last $5 \mathrm{~h}$ of pregnancy. In women the onset of copious milk secretion does not begin until 3-4 d post-partum ${ }^{2}$, and it is significant that citrate in samples of secretion obtained from the wife of a colleague on the day of delivery was low and then increased to reach a peak on day 4 (Fig. 1).

Milk citrate is synthesised from glucose and acetate in the mammary gland of the goat ${ }^{2}$. The sudden marked increase in citrate thus indicates not only the onset of synthesis and secretion of this substance but of copious secretion as well.

We thank Maureen Hamon, who carried out the analyses and Mrs I. C. Johnson who obtained the human milk samples; and P. F. Bridge, P. W. Jones, H. H. Pope and Miss A. Schwabe for help with collecting cow samples.

M. PeAker

ARC Institute of Animal Physiology,

J. L. LINZELL
Received November 11; revised December 11, 1974.
1 Linzell, J. L., and Peaker, M., Physiol. Rev., 51, 564-597 (1971).
2 Cowie, A. T. and Tindal, J. S., The Physiology of Lactation (Arnold, London, 197i).
3 Hartmann, P. E., J. Endocr., 59, 231-247 (1973)
Reynolds, M., and Folley, S. J. (eds), Lactogenesis (Univ. Pennsylvania Press, Philadelphia, 1969)
5 Barry, J. M., Nature, 227, 415 (1970).
6 Linzeli, J. L., in Lactation (edit. by Larson, B. L., and Smith, V. R.) I, 143-225 (Academic, New York 1974).
7 Paterson, J. Y. F., and Linzell, J. L., J. Endocr., 62, 371-343 (1974)
8 Reynolds, M., in Lactogenesis (edit by Reynolds, M. and Folley, S. J.) 145-151, (Univ. Pennsylvania Press, Philadelphia, 1969)
Hardwick, D. C., Linzell, J. L., and Mepham, T. B., Biochem. J., 88, 21,3-220
10 White, J. C. D., and Davies, D. T., J. Dairy Res., 30 171-189 (1963).

\section{Isoenzymes of hexokinase in human muscular dystrophy}

OF the several genetically determined diseases called muscular dystrophy, the best known, most studied and most severe are the sex-linked Duchenne type and its more slowly progressing variant, the Becker type ${ }^{1}$. The aetiology of these dystrophies is unknown, although dystrophies associated with deficiencies of vitamins and other nutrients are known in animals, and myopathy in man may arise from causes as diverse as alcoholism, thyrotoxicosis, infection and autoimmunity ${ }^{2}$. Such variety of known myopathies gave little help to early searches for the biochemical cause of the genetically determined dystrophies ${ }^{3}$. Recent workers have turned to biochemistry in search of a specific lesion in protein synthesis and its control ${ }^{4-6}$, or to tissues other than muscle, for example, its motor innervation ${ }^{7-10}$ or vascular supply ${ }^{11}$. Clearly, a genetic lesion must be translated 